\title{
АППЛИКАЦИЯ В ДЕКОРЕ КЕРАМИЧЕСКИХ СОСУДОВ РАННЕГО ЖЕЛЕЗНОГО ВЕКА КАЗАХСТАНА*
}

\author{
(C) 2019 г. Ж.С. Калиева
}

\begin{abstract}
Представленная статья посвящена анализу керамических сосудов раннего железного века Казахстана, имеющих отличительную особенность в виде декоративных аппликаций. В ходе исследований изучен и проанализирован 191 керамический сосуд. Датируются сосуды ранним железным веком, хранятся в фондах научноисследовательских учреждений и музеев Казахстана. В числе изученных образцов в восьми случаях были обнаружены остатки аппликаций на поверхности керамических сосудов и фрагментах керамики, что определило необходимость выявления и изучения данного феномена в гончарной продукции раннего железного века на территории Казахстана. Изучение аппликаций как элемента декора керамических сосудов раннего железного века Казахстана до сих пор не являлось предметом отдельного исследования, и настоящая статья имеет цель актуализировать проблему выявления, систематизации и анализа феномена декорирования аппликацией керамических сосудов различных исторических периодов.
\end{abstract}

Ключевые слова: археология, Казахстан, Алтай, Жетысу, ранний железный век, керамика, декор, аппликация, олово, золото, металл

\section{Введение}

Специальное изучение керамических изделий Казахстана, в частности керамических сосудов утилитарного или иного назначения, имеет сложную и многолетнюю историю. По мере накопления опыта в изучении керамических коллекций с каждым годом выявляются новые данные не только о морфологии, технике и технологии изготовления сосудов, но и сведения о духовном мире древнего общества, которые могла отразить в керамике определенная группа древних и средневековых гончаров [Куз- нецова, Тепловодская, 1994; Ломан, 2003; Шевнина, 2014; Краева, 2015].

Если в изучении качественного состава сырья и способов изготовления керамики Казахстана с применением естественно-научных методов работа ведется в интенсивном русле, то иная сторона изучения керамических изделий и керамического производства, а именно выявление и определение неутилитарного назначения керамики, позволяющего открыть завесу над мировоззренческими основами древнего общества, имеет некий эпизодический характер. Вместе

*Работавыполненаприподдержке Комитетанауки Министерства образования и науки Республики Казахстан (ИРН проекта ВR05233709) 
с тем, изучение в сфере морфологии, техники и технологии изготовления керамических коллекций в последние годы стало иметь преимущественно статистическую направленность, когда определенный качественный состав и количество керамических сосудов позволяют обнаружить аналогии, определить ареал и хронологию отдельно взятой археологической культуры. Тем не менее, не все специалисты уделяют должное внимание проблемам определения не утилитарного назначения керамических сосудов в системе мировоззрения древних.

Bce названное в настоящий момент предопределяет необходимость выработки и определения конкретных критериев оценки места и назначения керамических сосудов как в быту, так и в обрядово-ритуальной, а также в эстетической составляющей древнего общества. Безусловно, данная трактовка и постановка проблемы не является обязующим постулатом к действию, а лишь имеет цель поднять вопрос и дискуссии на данную тему на страницах отечественных научных изданий.

\section{Методы и методика исследо- ваний}

Исследование проводилось в рамках историко-культурного подхода в изучении древнего гончарства, основанного на бинокулярной микроскопии, трасологии и физического моделирования, разработанного А.А. Бобринским [Бобринский, 1978, c. 11-15]. Выдвинутая им структура гончарного производства содержит 10 обязательных и две дополнительные ступени, которые между собой объединены в три последовательные стадии, такие, как подготовительная, созидательная и закрепительная [Бобринский, 1999, с. 8-11]. В данной работе внимание сосредоточено на тре- тьей закрепительной стадии: ступень 11 - конструирование служебных частей и ступень 12 - орнаментация поверхности керамических сосудов.

\section{Описание материала}

В представленной статье мы рассматриваем конкретную особенность, выявленную в декоре керамических сосудов раннего железного века Казахстана, которая может выступать как хронологический и региональный маркер, а также быть одним из критериев для выявления мировоззренческих аспектов в духовном мире ранних кочевников.

Таким образом, рассматриваемая в статье особенность в декорировании керамических сосудов ранних кочевников заключается в применении техники аппликации при изготовлении керамических изделий. Под аппликацией и техникой ее изготовления мы понимаем общеизвестное определение, т.е. способ создания орнаментов, изображений путём нашивания, наклеивания на ткань, бумагу и т.п. разноцветных кусочков какоголибо материала (ткань, бумага, мех, соломка и т. п.) другого цвета или выделки, а также орнамент, изображение, созданные по такому способу, придающему им особую рельефность. В нашем случае аппликацией выступают свидетельства и остатки от металлических вставок на поверхности керамических сосудов из памятников ранних кочевников Казахстана.

В ходе исследований керамических коллекций, хранящихся в фондах научно-исследовательских учреждений и музеев Казахстана (Институт археологии им. А.Х. Маргулана, Центральный государственный музей РК, Государственный историко-культурный заповедникмузей «Иссык», Музей археологии «Гылым Ордасы», Восточно- 

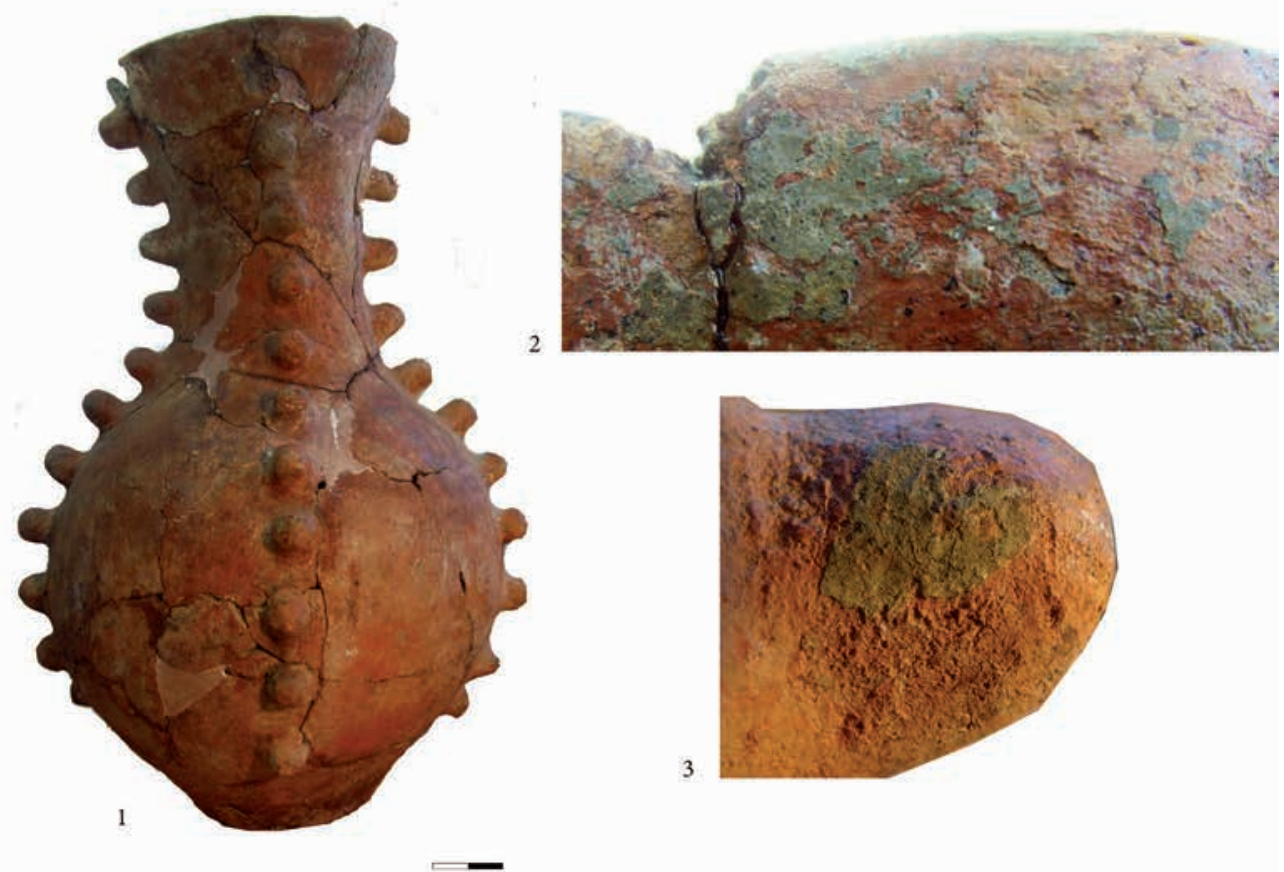

3

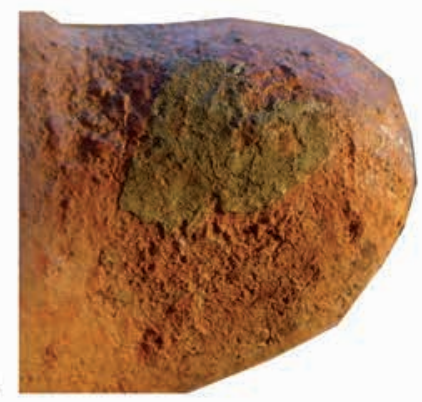

Рис. 1. Керамический сосуд. Берел, к. 10. 1 - общий вид; 2 - венчик сосуда с остатками адгезии и аппликаиии; 3 - фрагмент жемчужины с остатками адгезии и аппликащи. Раскопки ВКАЭ под руководством 3. Самашева. Фото Ж. Калиевой

Fig. 1. Ceramic vessel. Berel, barrow no. 10. 1 - general view; 2 -vessel corolla with remains of adhesion and applique; 3 - pearl fragment with remains of adhesion and applique. Excavations of the EKAE under the leadership of Z. Samashev.

Photo by Zh. Kalieva

Казахстанский областной историкокраеведческий музей, Алматинский областной историко-краеведческий музей им. М. Тынышбаева), был изучен и проанализирован 191 сосуд раннего железного века, из которых в восьми случаях были обнаружены остатки аппликаций на поверхности керамических сосудов и фрагментах керамики.

\section{Материаль могильника Берел}

В целом, аппликации и их остатки были выявлены на четырех сосудах из курганов могильника Берел в Восточном Казахстане, на одном сосуде и на двух фрагментах керамики из фонда Государственного историкокультурного заповедника-музея «Иссык» и на одном сосуде из фонда Му- зея археологии «Гылым Ордасы».

Преимущественно керамика с аппликациями превалирует в сосудах могильника Берел. Необходимо отметить, что керамическая коллекция Берела достаточно богата и разнообразна. Здесь преобладают высокие кувшины с овальным или округлым туловом, а также высоким горлом. Также многочисленны кувшины с шаровидным туловом и прямым горлом [Самашев, 2011].

Из всего разнообразия сосудов Берела необходимо выделить отдельную группу сосудов с аппликациями, которые обнаружены в погребениях курганов № 4, 10, 41, 73. Аппликации здесь представлены в виде остатков серой адгезии, а также остатков 
покрытий-лент из металла (фольги) на поверхности керамических сосудов. Ленты пластичного и блестящего металла серебристо-белого цвета предположительно изготовлены из олова, возможно с примесью золота или серебра. Лентами преимущественно покрыты венчики и шейки керамических сосудов.

Один из интересных сосудов с оригинальным декором происходит из берелского кургана № 10 [Самашев, 2011, с. 137-139]. Керамический сосуд высокий, узкогорлый и красноглиняный (рис. 1, 1-3), окрашен красной минеральной краской и декорирован по вертикали лепными жемчужинами. Жемчужины расположены снаружи в четырех вертикальных, симметрично расположенных по отношению друг к другу рядах по всей высоте сосуда (с венчика до придонной части сосуда). Размеры жемчужин составляют 2-2,5×1-1,5 см, расстояние между ними достигает 2-2,5 см. Всего насчитывается четыре вертикальных ряда по 11 жемчужин в каждом ряду, таким образом насчитывается 44 налепленных на сосуд жемчужины.

На поверхности жемчужин и по венчику фиксируются следы серебристого покрытия, химический состав которого, к сожалению, на данный момент определить не удалось. В целом, благодаря рядам налепных жемчужин, сосуд является уникальным.

На следующем сосуде из коллекции Берела, из кургана № 4 (рис. 2, 1-3), также выявлена серая адгезионная масса для аппликации и четко выделяется серебристое металлическое покрытие, собственно аппликация.
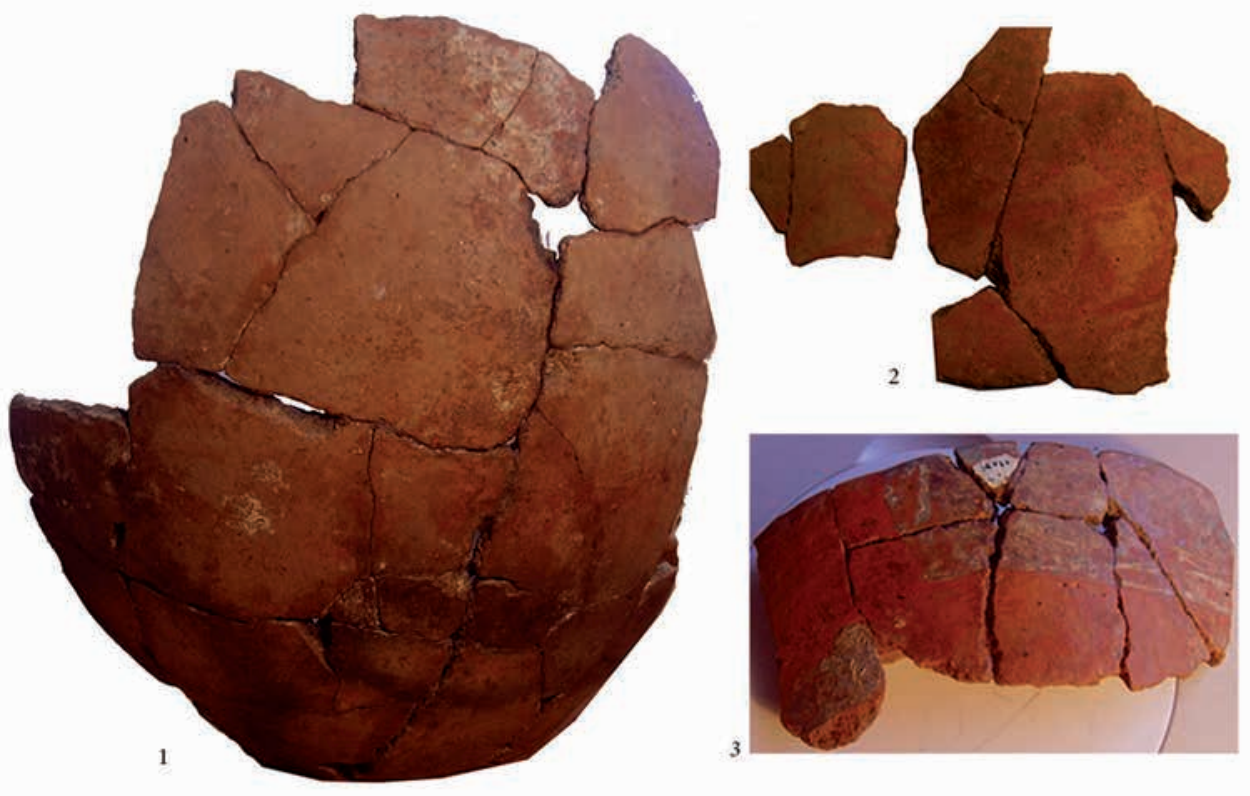

Рис. 2. Керамический сосуд. Берел, к. 4. 1 -общий вид; 2 - фрагмент боковинь сосуда с ангобом; 3 - венчик сосуда с остатками адгезии и аппликачии. Раскопки ВКАЭ под руководством 3. Самашева. Фото Ж. Калиевой

Fig. 2. Ceramic vessel. Berel, barrow no. 4. 1 - general view; 2 - a fragment of the side of the vessel with engobe; 3 - the corolla of the vessel with remains of adhesion and applique.

Excavations of the EKAE under the leadership of Z. Samashev, photo by Zh. Kalieva 
Помимо аппликации, сосуд декорирован расписным орнаментом, который выполнен минеральной краской красного оттенка, схожей с ангобом (рис. 2, 2). Орнамент разделен на четыре условные зоны. Первая представлена в виде волнистых линий, вторая - в виде растительного орнамента, третья - в виде стилизованного изображения птицы и четвертая завершает композицию волнистыми полосами. Все четыре зоны разделены горизонтальными полосами (рис. 3).

Еще один сосуд с аппликацией из берелского кургана № 41 представлен кувшином с широким устьем, прямой шейкой, с грушевидным слегка раздутым туловом и плоским дном. Поверхность данного сосуда обработана твердым предметом. Также встречаются следы выбивания колотушкой. По краю венчика и по горловине сосуда отчетливо видны следы и остатки ленты серебристого покрытия, сосуд также орнаментирован кольчатыми вдавлениями палочкой. Следы адгезионной массы и остатки аппликации в виде металлической ленты фиксируются по шейке и по венчику сосуда (рис. 4, 1-4).

Кувшин из берелского кургана № 73 также декорирован аппликацией. Сосуд представляет собой зауженный ко дну кувшин с вытянутой шейкой, раздутым грушевидным туловом. По венчику сосуда фиксируются следы серебристого покрытия в форме ленты шириной 1,5 см [Калиева, 2013, с. 228]. Местами по сосуду отмечена сероватая адгезионная масса (рис. 5, 1, 2).

В целом, декор керамики Берела достаточно разнообразен. В ходе анализа орнамента керамических
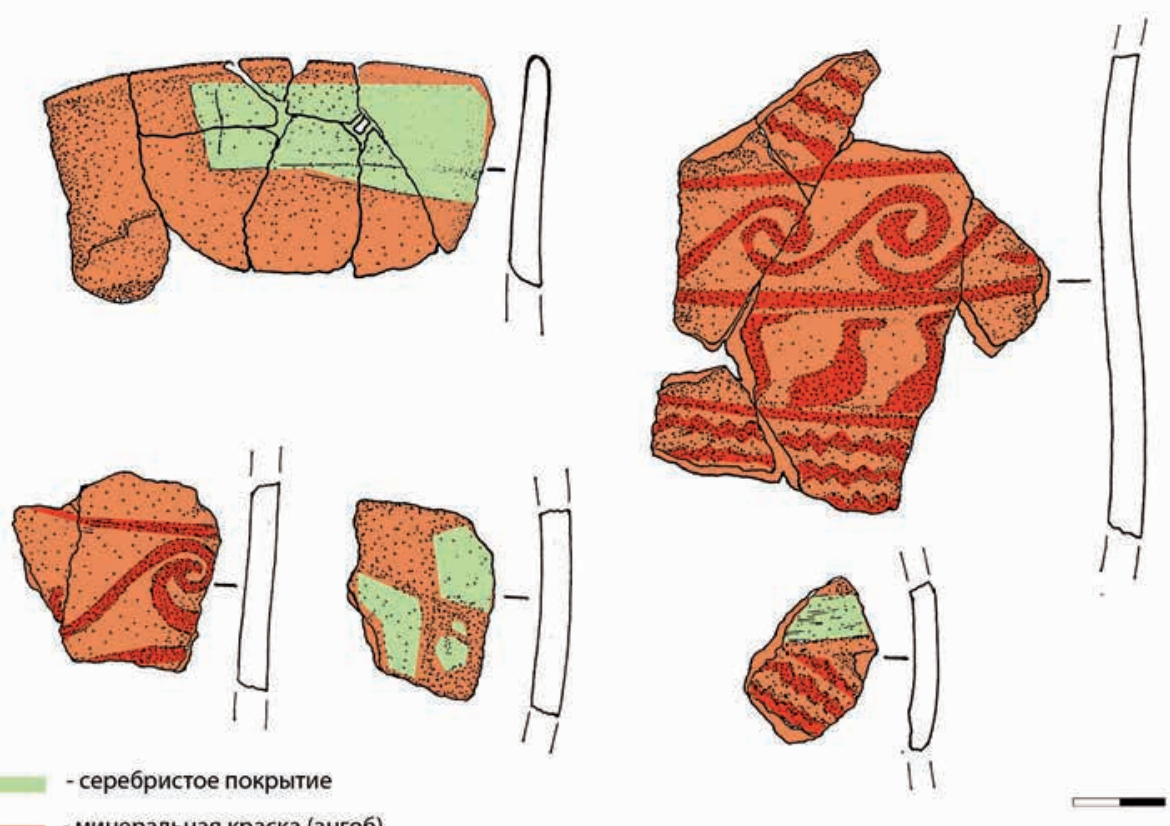

серебристое покрытие
минеральная краска (ангоб)

Рис. 3. Керамический сосуд. Берел, к. 4. Прорисовка Биримжанова М.

Fig. 3. Ceramic vessel. Berel, barrow no. 4. Drawing by Birimzhnov M. 


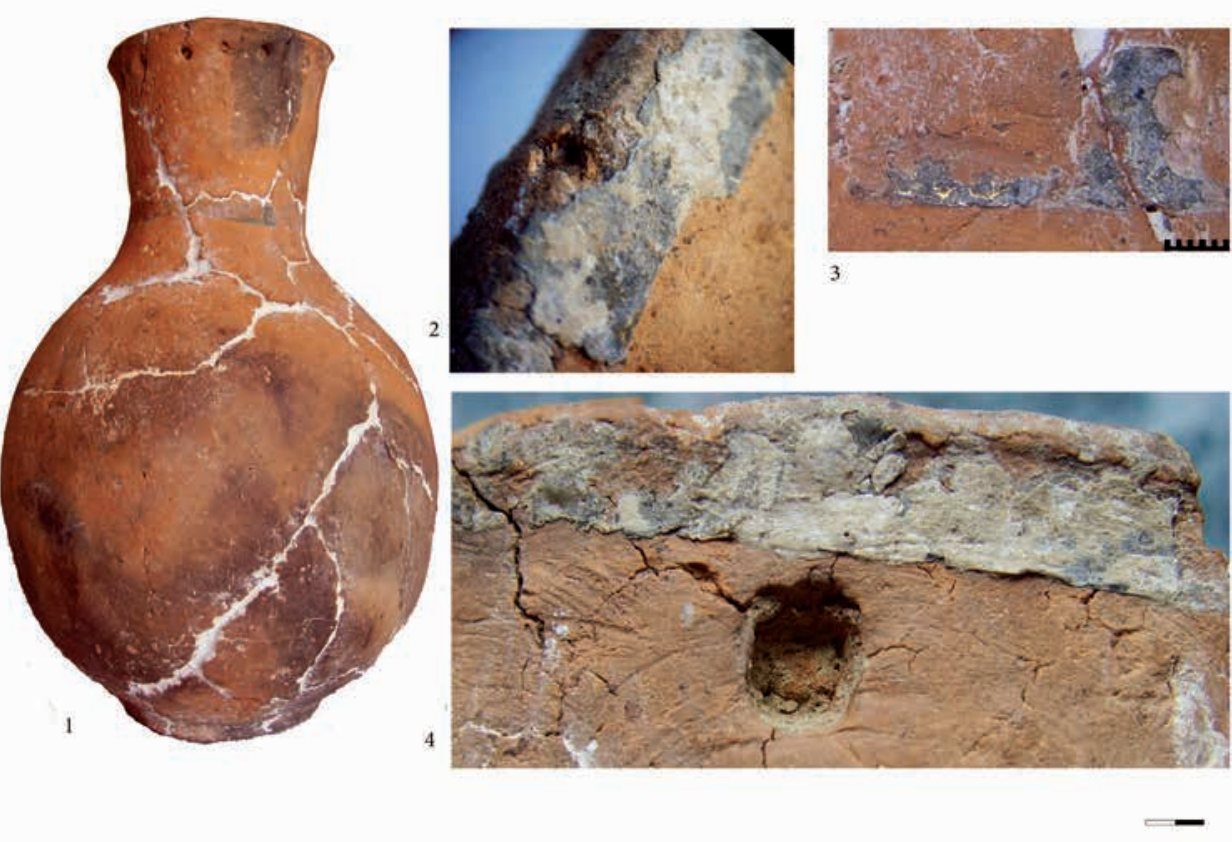

Рис. 4. Фрагменты керамического сосуда. Берел, к. 41. 1 -общий вид; 2, 4-венчик сосуда с остатками адгезии и аппликаџии; 3 - шейка сосуда с остатками адгезии и аппликации. Раскопки ВКАЭ под руководством 3. Самамева. Фото Ж. Калиевой

Fig. 4. Fragments of a ceramic vessel. Berel, barrow no. 41. 1 -general view;

2, 4- the corolla of the vessel with the remains of adhesion and appliqué; 3 - neck of the vessel with adhesion and applique remains.

Excavations of the EKAE under the leadership of Z. Samashev, photo by Zh. Kalieva

сосудов были зафиксированы прочерченные геометрические символы, треугольники, опущенные вершиной вниз, овальные полукруги, круги, вдавление палочкой, налепной валик и лепные жемчужины. Наличие столь широкого разнообразия в декорировании сосудов берелской керамической коллекции, возможно, указывает на существование локальной системы знаков и символов, со сложной традицией отображения орнамента на поверхности сосудов ранними кочевниками. На данный вывод наталкивает ряд примеров, а именно наличие и особое расположение лепных деталей, зональное разделение сосуда и наличие аппликаций. Все названное, несомненно, указывает не только на высокое мастерство гончарного производства племен раннего железного века Алтая, но и свидетельствует о сложном и глубоком духовном мире ранних кочевников Берела.

Наличие аппликаций в керамических коллекциях Берела определило необходимость выявления и изучения данного феномена в гончарной продукции раннего железного века на территории Казахстана. С этой целью были исследованы керамические коллекции, хранящиеся в фондах музеев Казахстана.

Анализ материала в музеях Казахстана

На данный момент были исследованы 40 керамических сосудов и отдельных фрагментов керами- 


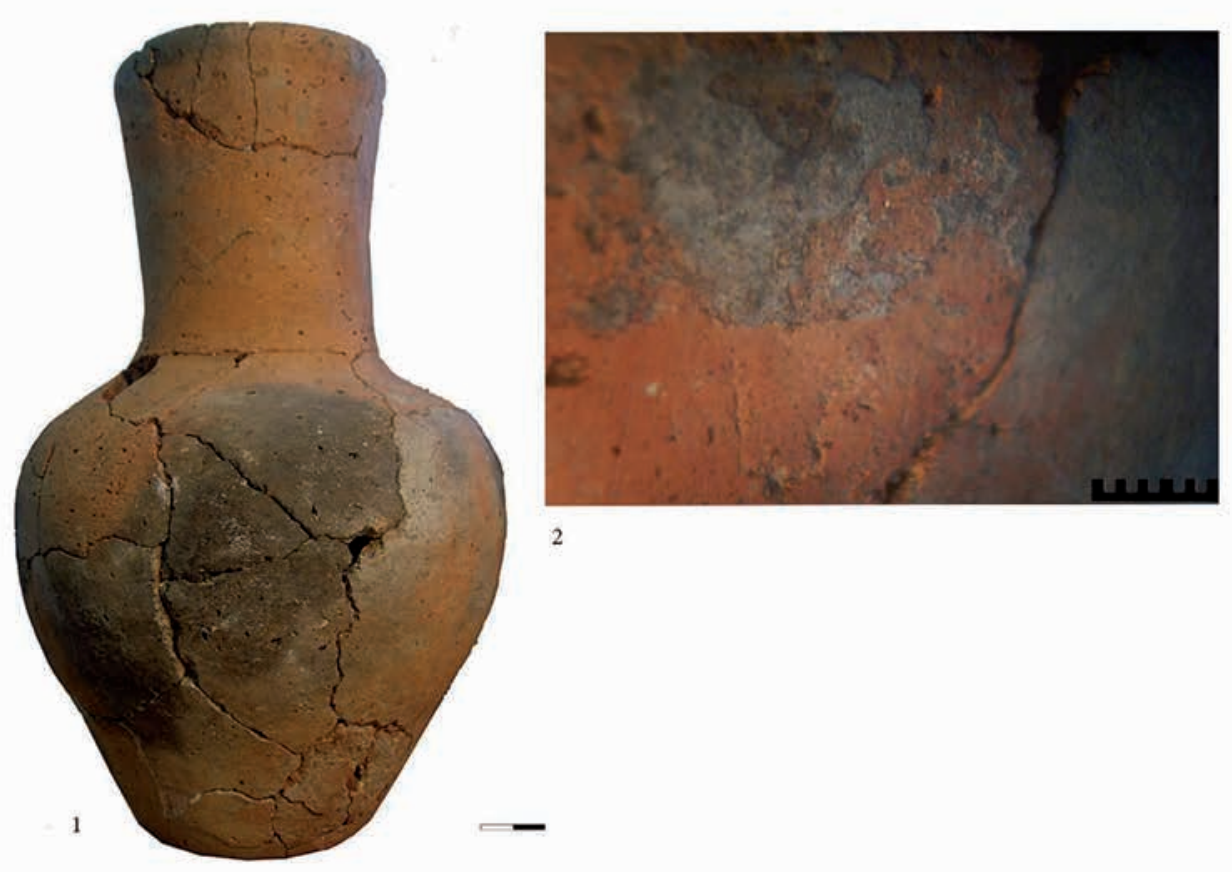

Рис. 5. Керамический сосуд. Берел, к. 73. 1 - общиий вид; 2 - венчик сосуда с остатками адгезии и аппликации.

Раскопки ВКАЭ под руководством 3. Самашева. Фото Ж. Калиевой

Fig. 5. Ceramic vessel. Berel, barrow no. 73. 1-general view; 2 - the corolla of the vessel with the remains of adhesion and applique.

Excavations of the EKAE under the leadership of Z. Samashev, photo by Zh. Kalieva

ки, обнаруженных в разные годы на территории Восточного Казахстана. Большая часть керамических коллекций названного региона хранится в фондах Восточно-Казахстанского областного историко-краеведческого музея в г. Усть-Каменогорск [Калиева, 2014, с. 316-320]. Кроме того, были изучены сосуды раннего железного века, обнаруженные в разные годы на территории Жетысу, часть из которых хранится в фондах Алматинского областного историко-краеведческого музея им. М. Тынышбаева. Здесь были исследованы 17 керамических сосудов.

Большой пласт керамических коллекций хранится в фондах и экспо- зициях Центрального государственного музея РК. К сожалению, нам удалось исследовать в данном музее лишь небольшую часть керамики, а именно 18 целых сосудов.

В числе исследованных керамических коллекций названных музеев, к сожалению, не зафиксированы факты наличия аппликаций в декорировании сосудов. Но, тем не менее, исследование и анализ керамики в фондах данных музеев необходимо продолжать в будущем.

Сосуд с аппликациями был выявлен и исследован в фондах Музея археологии «Гылым Ордасы». В фондах музея были проанализированы 23 керамических сосуда, из них лишь на 
поверхности одного была выявлена аппликация (рис. 6, 1, 2). Аппликация расположена на венчике и представлена в виде остатков симметрично расположенных металлических пластин. К сожалению, идентифицировать исследованный сосуд, определить год и местонахождение артефакта не удалось, что затрудняет привязку данной находки к определенному региону. Тем не менее, опираясь на морфологические особенности, можно предположить, что он изготовлен в конце I тыс. до н.э. - начале I тыс. н.э.

Еще один сосуд из Алматинской области происходит из кургана № 59 могильника Каратума [Байпаков и др., 2016, с. 241-243], два фрагмента керамики с аппликацией из кургана № 4 могильника Алатау, Алматинской обл.
[Сейткалиев, 2015, с. 98-100] были выявлены в фондах Государственного историко-культурного заповедника музея «Иссык». Здесь проанализировано 73 целых керамических сосуда эпохи раннего железа.

Один сосуд с аппликацией представляет собой чашу (рис. 7,1 ). Невооруженным глазом остатки аппликации на данном сосуде не прослеживаются. Лишь с применением стереоскопического бинокулярного микроскопа МБС-10 удалось выявить белую адгезионную массу с остатками металлической фольги (позолотой) на венчике (рис. $7,2,3$ ) и тулове (рис. 7,4 ) сосуда. Также в постоянной экспозиции музея находятся два фрагмента со вставками из золотой фольги, происходящие из кургана № 4 мо-

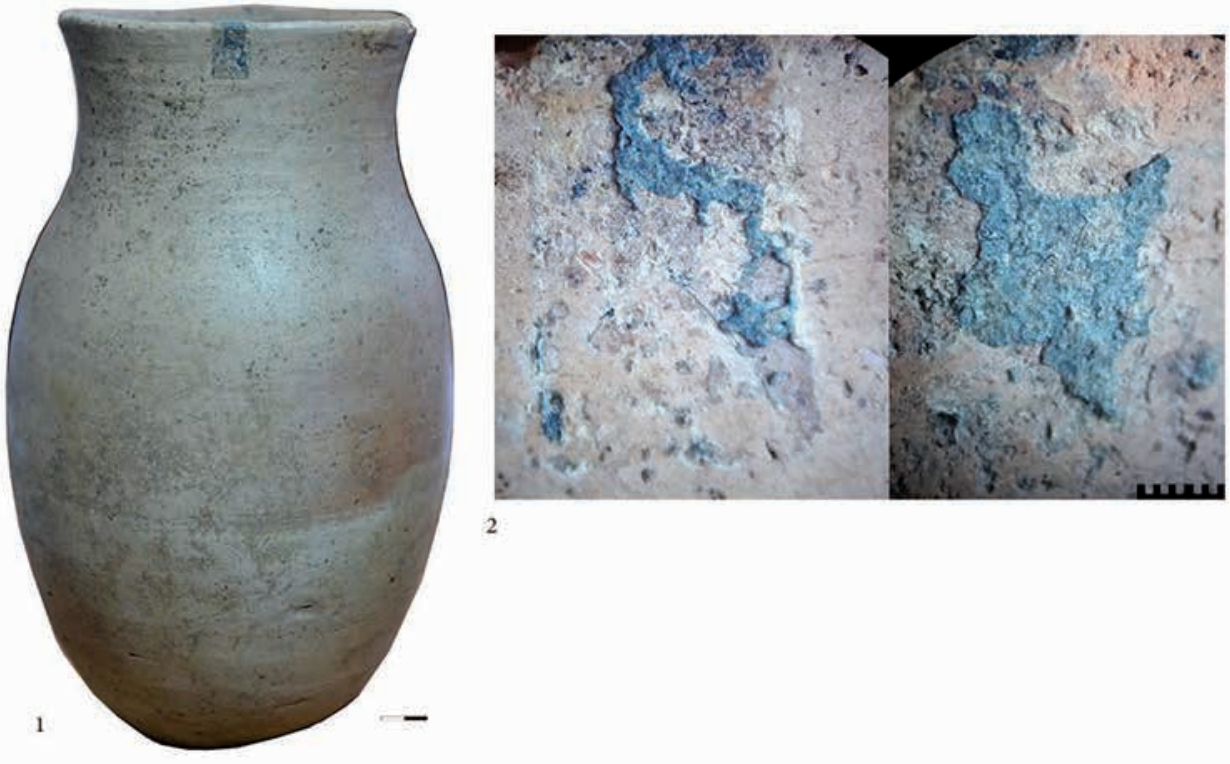

Рис. 6. Керамический сосуд с остатками адгезии и аппликаиией. Фонд Археологического музея «Гыльмм ордасы», иифр МА24/3, ГОМА № 309. 1 - общчий вид; 2 - венчик сосуда с остатками адгезии и аппликацчии. Фото Ж. Калиевой

Fig. 6. Ceramic vessel with adhesion residues and applique. Fund of the Archaeological Museum "Gylym Ordasy», cipher MA24/3, GOMA no.309. 1 - general view; 2 - the corolla of the vessel with the remains of adhesion and applique. Photo by Zh. Kalieva 
гильника Алатау (рис. 8). В связи с тем, что доступ к исследованию был ограничен, детальный анализ данных фрагментов не был произведен. Вместе с тем, наличие крепежных отверстий на одном фрагменте золотой фольги ставит под сомнение, что данный экземпляр был использован в качестве аппликации в декоре указанного фрагмента керамики и возможно использовался для декорирования одежды либо иного убранства.

Таким образом, необходимо отметить, что применение аппликаций в декорировании керамических сосудов раннего железного века на данный момент выявлено лишь в памятниках Алтая и Жетысу и требует дальнейшего проведения комплексных исследований керамических коллекций из других регионов Казахстана.

Обсуждение материала

Если провести широкие аналогии в технике декорирования керамических сосудов, необходимо отметить находку, сделанную А.И. Тереножкиным в 1950 г. близ села Глеваха (Васильковский р-н, Киевская обл.). В ходе изучения кургана раннего железного века им была обнаружена

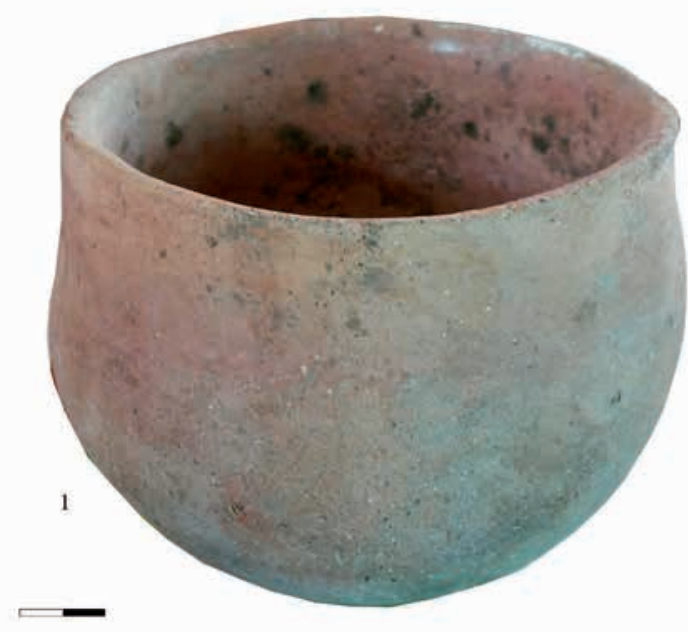

2

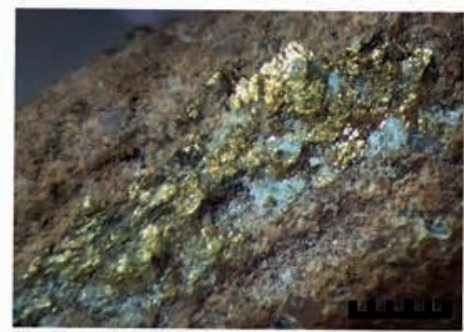

3

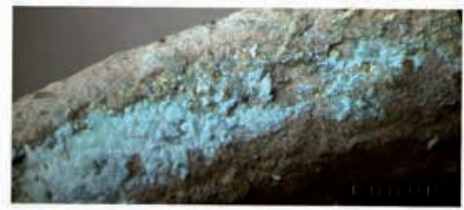

4

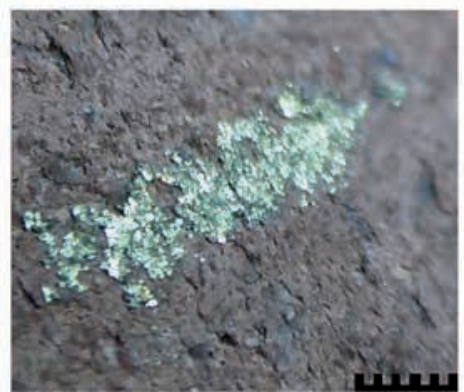

Рис. 7. Керамический сосуд. Мог. Каратума, к. 59. Фонд Государственного историкокультурного заповедника музея «Иссык», иифр ЕКМ НТК 107 (по: [Байпаков и др., 2016]). 1 - общчй вид; 2 - венчик сосуда с остатками адгезии и аппликаџией (позолотой); 3 - венчик сосуда с остатками адгезии и аппликацчией (позолотой); 4 - тулово сосуда с остатками адгезии и аппликаџией (позолотой). Фото Ж. Калиевой

Fig. 7. Ceramic vessel. The burial ground of Karatuma, borrow no. 59. Fund of the State Historical and Cultural Reserve of the Issyk Museum. Cipher EKM NTK 107

(by: [Baipakov et al, 2016]). 1 -general view; 2 - corolla of the vessel with adhesion residues and applique (gilding); 3 - corolla of the vessel with adhesion residues and applique (gilding); 4 - body vessel with adhesion residues and applique (gilding).

Photo by Zh. Kalieva 


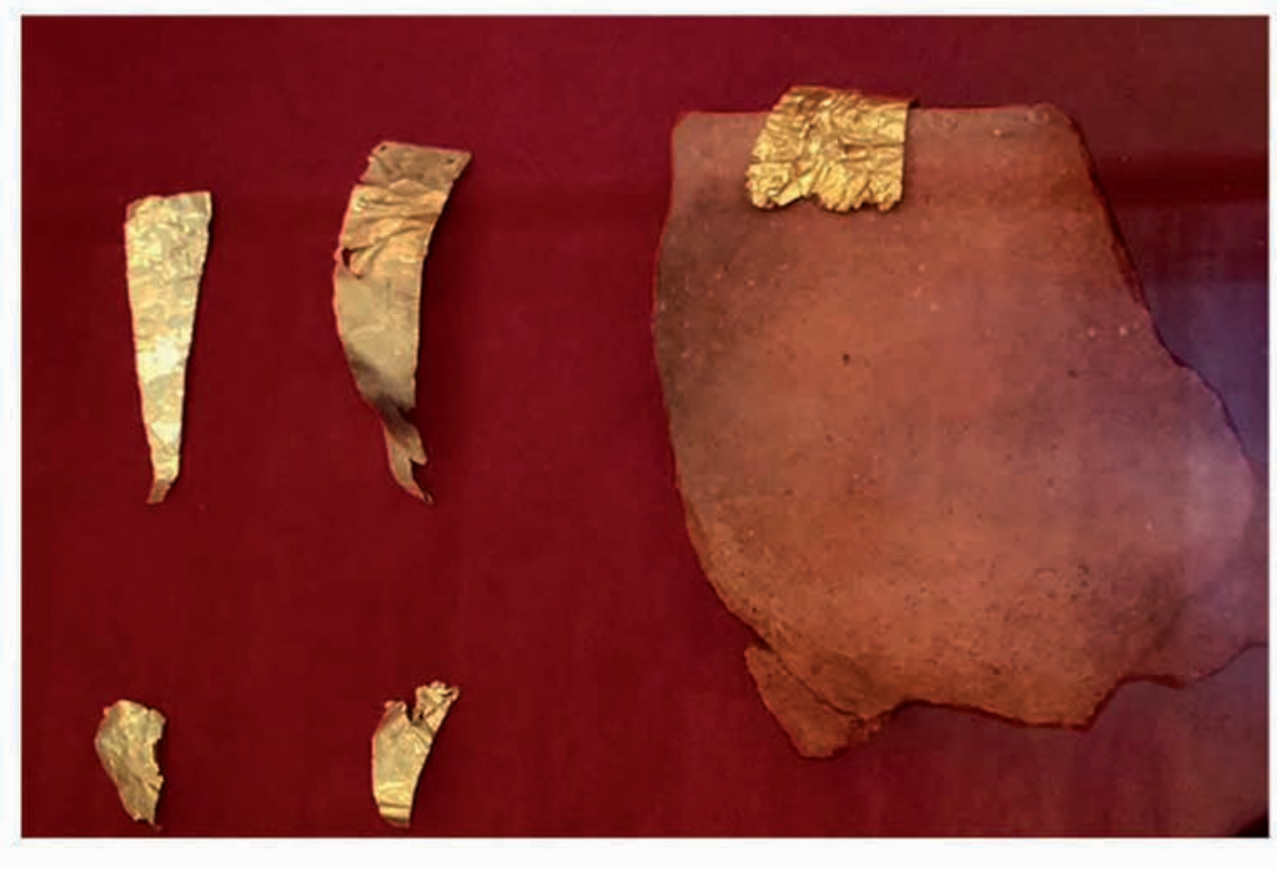

Рис. 8. Фрагмент керамического сосуда с листами золотой фольги. Могильник Алатау 2010, к. 4. Постоянная экспозищия Государственного историко-культурного заповедника музея «Иссык» (по: [Сейткалиев, 2015]). Фото Ж. Калиевой

Fig. 8 - a fragment of a ceramic vessel with sheets of gold foil. Burial ground Alatau, 2010, borrow no. 4. Permanent exhibition of the State Historical and Cultural Reserve of the

Issyk Museum (by: [Seitkaliev, 2015]). Photo by Zh. Kalieva

корчага высотой 74 см [Тереножкін, 1954, с. 80-97]. Сосуд примечателен тем, что орнаментирован по плечику тремя округлыми вертикальными выступами и имеет следы от накладных золотых бляшек и лент. Также как и в случае с сосудами из Алтая и Жетысу на месте расположения (крепления) пластин сохранилась белесая адгезия. Подробное исследование данного сосуда провела сотрудник Института археологии НАН Украины Е.Е. Фиалко.

Е.Е. Фиалко, опираясь на хронологическую датировку находок из Глевахи (конец VII - начало VI в. до н.э.), предполагает, что традиция в орнаментации сосудов Алтая с применением аппликации, возможно, за- имствована из Европейской Скифии и была ассимилирована местными племенами [Фиалко, 2008, с. 33]. На наш взгляд, данная гипотеза является спорной и требует более тщательного изучения. Мы солидарны с мнением В.И. Молодина, считающего регионы Средней Азии и Казахстана как некую прародину оформления форм и специфических черт в декоре посуды ранних кочевников [Молодин, 2000, c. 113].

Аналогию использования аппликаций на поверхности сосудов Берела можно также найти в керамических изделиях пазырыкской культуры. В случае с анализом сосудов из могильников Ак-Алаха-3 и Берел можно отметить, что прямой аналоги- 
ей выступают лишь морфологические особенности, а именно форма, строение, техника внешней обработки и орнаментация. Вместе с тем, в обоих случаях используется аппликация, но разница заключается в материале исполнения декора. В керамике АкАлаха-3 использованы аппликации из кожи [Полосьмак, 1994, с. 69-70], тогда как на образцах из мог. Берел металл.

\section{Bblводы}

Подводя итог, необходимо отметить, что в изучении аппликаций в декоре керамических сосудов раннего железного века Казахстана четко определяется круг вопросов и проблем как прикладного, так и концептуального характера.

Среди прикладных проблем необходимо назвать отсутствие конкретных сведений о химическом составе непосредственно металлических или иных вставок на поверхности изделий, не только из памятников Казахстана, но Евразийских степей в целом. Кроме того, актуально определение химического состава адгезионной массы. Проблема анализа состава скрепляющего вещества, а именно ответ на вопрос «Каково происхождение склеивающей массы - органическое или минеральное?» - остается открытым.

Среди концептуальных можно назвать проблему изучения места появления и определение ареала феномена декорирования с применением аппликаций, а также установление цели и назначения специфического приема орнаментации. Носила ли данная традиция утилитарный характер или имела некие ритуальные, обрядовые цели. Изготавливалась ли посуда специально, либо же производилась повсеместно в быту. Для поиска ответа на данный вопрос необ- ходимо проведение комплексных исследований, что требует изучение не только погребений, но и поселений раннего железного века.

Еще одним важным и нерешенным аспектом в изучении керамических коллекций, в том числе в исследовании аппликаций в декорировании керамики, можно назвать проблему терминологии. Необходимо отметить, что в рамках статьи, а именно в историографии проблемы применения аппликаций в керамике, чаще используется термин «цементирующая масса» [Тереножкін, 1954; Фиалко, 2008], что, на наш взгляд, является некорректным определением, Термин «цементирующий» конкретизирует состав склеивающей массы, тогда как использованный нами термин «адгезия» определяет процесс (т.е. склеивание, спайка, скрепление). Таким образом, клейкое, скрепляющее вещество минерального либо органического происхождения, необходимое для фиксации элементов аппликации на поверхности керамического изделия, предлагается именовать как адгезия или адгезионная масса.

В целом, в ходе исследовательских работ остро встал ряд методологических и организационных проблем в изучении аппликаций в декоре керамических сосудов. Ранее было отмечено, что в отдельных случаях аппликации были видны невооруженным глазом, в других остатки аппликаций были выявлены с применением бинокулярной микроскопии. Этот факт наталкивает на мысль о необходимости внедрения и применения более щадящей камеральной обработки обнаруженных фрагментов и керамических сосудов. Более тщательная первичная очистка позволит сохранить достаточно хрупкие, а иногда и микроскопические элементы декора керамических сосудов. 
Хотя из всей массы представленных в статье исследованных артефактов лишь небольшой процент составила керамическая посуда с аппликациями, это не говорит о том, что работа в данном направлении малоперспективна. Вполне вероятно, что для изучения данного феномена необходимо привлечение широкого спектра специалистов как гуманитарного, так и естественнонаучного профиля, и разработки новых методик в изучении сложносоставного декора и аппликаций в орнаментации сосудов, что, безусловно, позволит приоткрыть завесу над сложным и интересным миром древних.

Благодарности. Автор выражает искреннюю признательность ру- ководителю Восточно-Казахстанской археологической экспедиции 3. Самашеву за предоставленную возможность работы с керамической коллекцией могильника Берел. Автор благодарен руководству и сотрудникам Центрального государственного музея РК, Государственного историкокультурного заповедника-музея «Иссык», музея археологии «Гылым Ордасы», Восточно-Казахстанского областного историко-краеведческого музея, Алматинского областного историко-краеведческого музея им. М. Тынышбаева за предоставленную возможность работать с керамическими коллекциями, хранящимися в фондах.

\section{ЛИТЕРАТУРА}

1. Бобринский А.А. Гончарство Восточной Европы. Москва: Наука, 1978. 269 с.

2. Бобринский A.A. Гончарная технология как объект историко-культурного изучения // Актуальные проблемы изучения древнего гончарства: коллективная монография. Научн. ред. Бобринский А.А., сост. Васильева И.Н., Салугина Н.П. Самара: СГПУ, 1999. С. 8-11.

3. Байпаков К.М., Воякин Д.А., Захаров С.В. Могильник Каратума. Некрополь раннего железного века в Семиречье. Алматы: «Археологическая экспертиза», 2016. $672 \mathrm{c}$.

4. Калиева Ж.С. Результаты технико-технологического анализа керамических коллекций Береля // Труды филиала Института археологии им. А.Х. Маргулана в г. Астана. 2013. Т. II. С. 226-229.

5. Калиева Ж.С. Технико-технологический анализ керамических коллекций из памятников раннего железного века Восточного Казахстана // Всадники великой степи: традиции и новации. Труды филиала Института археологии им. А.Х. Маргулана в г. Астана. 2014. T. IV. C. 316-320.

6. Краева Л.А. Бытовое и сакральное использование керамики у сарматов Южного Приуралья и Западного Казахстана // Самарский научный вестник. 2015. № 3 (12). C. 90-99.

7. Кузнецова Э.Ф., Тепловодская Т.М. Древняя металлургия и гончарство Центрального Казахстана. Алматы: Гылым, 1994. 207 с.

8. Ломан В.Г. Общие принципы выделения историко-культурной информации по данным гончарной технологии // Степная цивилизация Восточной Евразии. Т. 1. Древние эпохи. Ред. М. Жолдасбеков. Астана: Күлтегін, 2003. С. 146-151.

9. Молодин В.И. Культурно-историческая характеристика погребального комплекса кургана № 3 памятника Верх-Кальджин II // Феномен алтайских мумий: коллективная монография. Отв. ред.: Молодин В.И., Деревянко А.П. Новосибирск: издво ИАЭт СО РАН, 2000. С. 86-120. 
10. Полосьмак Н.В. «Стерегущие золото грифы» (Ак-Алахинские курганы). Новосибирск: Наука, 1994. 127 с.

11. Самашев 3. Берел. Berel. Алматы: «Таймас», 2011. 236 с.

12. Сейткалиев M.K. Аварийные раскопки большого кургана в окрестностях г. Алматы // Ранний железный век Евразии от архаики до рубежа эр. Центры, периферии и модели культурных взаимодействий: матер. тематич. научн. конф. (г. СПб., 2327 ноября 2015 г.). Отв. ред. Д.Г. Савинов. СПб.: «Скифия-принт», 2015. С. 98-100.

13. Тереножкін O.I. Курган біла с. Глеваха // Археологія. 1954. Т. IX. С. 80-97.

14. Фиалко E.E. Аппликация в декоре лепной посуды раннего железного века // PA. 2008. № 1. C. 28-34.

15. Шевнина И.В. Гончарство неолитических племен Торгая. Материалы и исследования по археологии Казахстана. Астана: Филиал Института археологии им. А.Х. Маргулана, 2014. Т. 4. 235 с.

\section{Сведения об авторе:}

Калиева Жанаргуль Сериковна - магистр археологии, научный сотрудник, Институт археологии им. А.Х. Маргулана (г. Нур-Султан, Казахстан); zhkalieva@mail.ru

\section{ҚАЗАҚСТАННЫН ЕРТЕ ТЕМІР ДӘУІРІНІҢ ҚЫШ ЫДЫСТАРЫНЫҢ БЕТІНДЕГІ АППЛИКАЦИЯ}

\section{Ж.С. Калиева}

Ұсынылған мақала сәндік қолданба түрінде өзіндік ерекшелігі бар ерте темір дәуіріндегі қыш ыдыстарды талдауға арналған. Зерттеу барысында ерте темір дәуірінен қалған және Қазақстанның ғылыми-зерттеу мекемелері мен мұражайларының қорларында сақталған 191 қыш ыдыстар зерттелді және талданды. Зерттелген керамикалық ыдыстардың ішінде сегіз жағдайда керамикалық ыдыстардың беткі жағындағы қалдықтар мен керамика фрагменттері табылды, олар Қазақстандағы ерте темір дәуірінің қыш бұйымдарындағы осы құбылысты анықтау және зерттеу қажеттілігін анықтады. Қазақстанның ерте темір дәуіріндегі керамикалықыдыстардағы декор элементі ретінде қосымшаларды зерттеу әлі жеке зерттеу тақырыбы болған жоқ, және бұл мақала әртүрлі тарихи кезеңдердегі керамикалық ыдыстардағы декорация құбылыстарын анықтау, жүйелеу және талдау мәселелерін өзекті етуге бағытталған.

Түйін сөздер: археология, Қазақстан, Алтай, Жетісу, ерте темір дәуірі, қыш ыдыс, сәндеу, аппликация, қалайы, алтын, метал

\section{APPLIQUE WORK IN THE DECOR OF CERAMIC VESSELS OF THE EARLY IRON AGE OF KAZAKHSTAN}

\section{Zh.S. Kalieva}

Presented article is devoted to the analysis of ceramic vessels of the early Iron Age of Kazakhstan, which have a distinctive feature in the form of decorative appliqué works. During the research, 191 ceramic vessels with dates of the early Iron Age, which are stored in the fund of Scientific research institutions and museums of Kazakhstan, were studied and analyzed. Among the studied exemplars in eight cases were found remains of appliques on a surface of ceramic vessels and fragments of ceramics that defined need of identification and studying of this phenomenon for pottery of the early Iron Age in the territory of Kazakhstan. The study of ornaments as an element of decor in ceramic vessels of the early Iron Age of Kazakhstan has not yet been the subject of a separate study, and this article aims to actualize the problem of identifying, systematizing and analyzing the phenomenon of decorating applique works in ceramic vessels of various historical periods. 
Keywords: archaeology, Kazakhstan, Altai, Zhetysu, the early iron age, ceramics, decor, applique, tin, gold, metal

\section{REFERENCES}

1. Bobrinsky, A. A. 1978. Goncharstvo Vostochnoi Evropy (Pottery of Eastern Europe). Moscow: "Nauka" Publ. (in Russian).

2. Bobrinsky, A. A. 1999. In: Bobrinsky, A. A. (ed.). Aktualnye problemy izucheniya drevnego goncharstva (Actual problems of the study of ancient pottery). Samara: Samara State Pedagogical University Publ., 8-11(in Russian).

3. Baipakov, K. M., Voyakin, D. A., Zakharov, S. V. 2016. Mogilnik Karatuma. Nekropol rannego zheleznogo veka $v$ Semirechye (Karatuma burial ground. Necropolis of the Early Iron Age in Semirechye). Almaty: Arkheologicheskaya ekpertiza (in Russian).

4. Kalieva, Zh. S. 2013. In: Trudy filiala Instituta arkheologii im. A.Kh. Margulana v Astane (Proceedings of a branch of the A.Kh. Margulan Institute of Archeology in Astana), II, 226-229 (in Russian).

5. Kalieva, Zh. S. 2014. In: Vsadniki velikoi stepi: tradicii i novacii. Trudy filiala Instituta arkheologii im. A.Kh. Margulana v Astane (Horsemen of the great steppe: traditions and innovations. Proceedings of a branch of the A.Kh. Margulan Institute of Archeology in Astana), IV, 316-320 (in Russian).

6. Kraeva, L. A. 2015. In: Samara Scientific Bulletin, 3 (12), 90-99 (in Russian).

7. Kuznetsova, E. F., Teplovodskaya, T. M. 1994. Drevnyaya metallurgiya I goncharstvo Tsentralnogo Kazakhstana (Ancient metallurgy and pottery of Central Kazakhstan). Almaty: "Gylym" Publ. (in Russian).

8. Loman, V. G. 2003. In: Joldasbekov, M. (ed.). Stepnaya civilizaciya Vostochnoi Evrazii. T. 1. Drevnie epohi (Civilization of Eastern Eurasia. T. 1. Ancient eras). Astana: "Kultegin" Publ., 146-151 (in Russian).

9. Molodin, V. I. 2000. In: Molodin, V. I., Derevyanko, A. P. (eds.). Fenomen altaiskih mumii (The phenomenon of Altai mummies). Novosibirsk: IAEt SB RAS Publ, 86120 (in Russian).

10. Polosmak, N. V. 1994. «Steregushchiye zoloto grify» (Ak-Alakhskiye kurgany) ("Vultures guarding gold" (Ak-Alakh mounds)). Novosibirsk: "Nauka” Publ. (in Russian).

11. Samashev, Z. 2011. Berel. Almaty: "Taymas" Publ. (in Russian, in English).

12.Seytkaliev, M. 2015. In: Savinov, D. G. (ed.). Ranniy zheleznyy vek Yevrazii ot arkhaiki do rubezha er (The Early Iron Age of Eurasia from Archaic to the Turn of the Era). Saint Petersburg: "Scythia-print" Publ., 98-100 (in Russian).

13. Terenozhkín, O.I. 1954. In Arkheologiya (Archaeology), IX, 80-97 (in Ukrainian).

14. Fialko, E. E. 2008. In Rossiiskaya arkheologiya (Russian archaeology), 1, 28-34 (in Russian).

15. Shevnina, I. V. 2014. Goncharstvo neoliticheskikh plemen Torgaya (Pottery trading of Neolithic Torgay). Astana: Branch of the A.Kh. Margulan Institute of Archeology Publ. (in Kazakh, Russian and English).

\section{About the Author:}

Kalieva Zhanargul S. Magistr of archeology, scientific researcher, A.Kh. Margulan Archeology Institute, Nur-Sultan, Kazakhstan; zhkalieva@mail.ru

\footnotetext{
Мүдделер қақтығысы туралы ақпаратты ашу. Автор мүдделер қақтығысының жоқтығын мәлімдейді. / Раскрытие информации о конфликте интересов. Автор заявляет об отсутствии конфликта интересов. / Disclosure of conflict of interest information. The author claim no conflict of interest.

Мақала туралы ақпарат / Информация о статье / Information about the article. Редакцияға түсті / Поступила в редакцию / Entered the editorial office: 25.08.2019. Рецензенттер мақұлдаған / Одобрено рецензентами / Approved by reviewers: 02.09.2019. Жариялауға қабылданды / Принята к публикации / Accepted for publication: 09.09.2019.
} 